Rapp. Grønlands geol. Unders. 99, 119-120 (1980)

\title{
COLLECTION OF STREAM SEDIMENTS FOR A RECONNAISSANCE GEOCHEMICAL SURVEY FROM THE PEARY LAND REGION, NORTH GREENLAND
}

\author{
Niels Henriksen
}

The regional geochemical reconnaissance survey initiated in 1978 (Ghisler et al. 1979) was continued with the collection of stream sediments, as an integral part of the systematic geological mapping programme. The purpose of this programme is to provide information for an evaluation of the mineral potential and to obtain general geochemical data. A total of c. 460 stream sediment samples representing a wide geographic spread were collected mainly between Hagen Fjord and Johannes V. Jensen Land (fig. 1). The samples were collected with reference to the lithostratigraphical mapping units and the stratigraphical distribution is shown on fig. 54. In all c. 280 silt samples and c. 180 sand samples were collected. Nearly all geological mapping teams participated in the collecting of the material. While most teams collected the material as occasional samples only, one team (N. Henriksen) carried out special sampling of certain stratigraphical sequences and in certain areas, in order to obtain material for a systematic evaluation of the geochemical working method. Approximately half of all samples were collected in this way and can be used to check the significance of the results obtained from the occasional samples.

Sampling was undertaken in relation to the local drainage system and generally streams of medium to small size were chosen.

Two types of stream sediments were collected - sand and silt. The silt samples were approximately $200 \mathrm{~g}$ and sand samples 1 litre.

The following information was noted at each locality: type of sample, stratigraphical level, lithology of bedrock in catchment area, stream width, colour of stream sediment and UTM coordinates.

The planned laboratory investigations will follow the same lines as with the 1978 samples (Ghisler \& Stendal; Steenfelt, this report).

Silt samples will be analysed using delayed neutron counting for $U$ determinations and using isotope excited $\mathrm{X}$-ray flourescence (EDX) for determination of the following elements: K, Ca, Ti, V, Cr, Fe, Ni, Cu, Zn, Ga, Pb, Sr, Rb, Y, Zr, Nb, Th. Atomic absorption spectrophotometry will be used to analyse for $\mathrm{As}, \mathrm{Ba}, \mathrm{Bi}, \mathrm{Co}, \mathrm{Sb}$. A. Steenfelt will coordinate the laboratory investigation of the silt samples.

The sand samples will be investigated by $M$. Ghisler and $H$. Stendal, who will make heavy mineral concentrates and investigate the material in polished sections and use ultra-violet light to look at certain fractions of the separated material.

\section{Reference}

Ghisler, M., Henriksen, N., Steenfelt, A. \& Stendal, H. 1979: A regional reconnaissance, geochemical survey in the Proterozoic - Phanerozoic platform succession of the Peary Land region, North Greenland. Rapp. Grønlands geol. Unders. 88, 85-91. 
STRATIGRAPHICAL UNIT

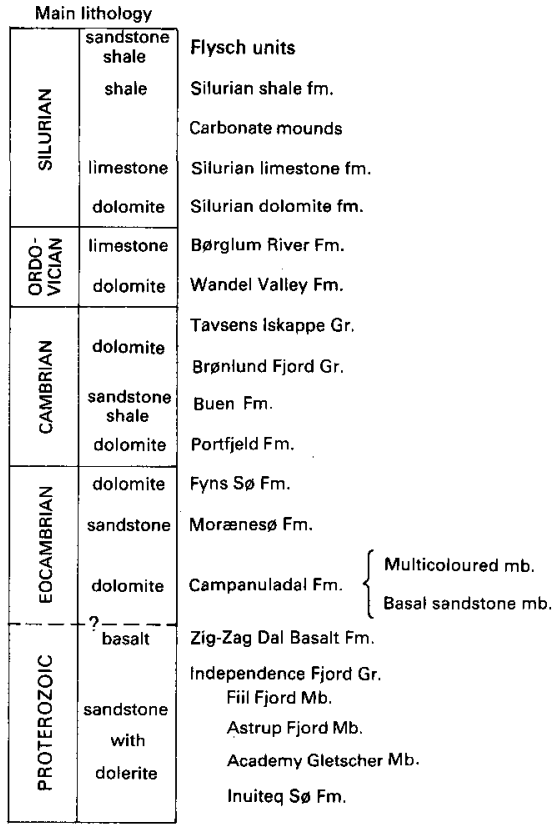

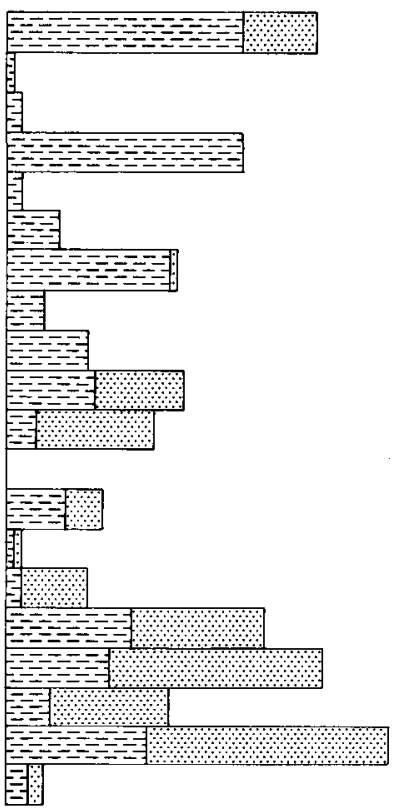

Kronprins Christian Land - Palaeozoic limestones, dolomites, shales

Fold belt north of Frederick E. Hyde Fjord

Mainly palaeozoic flysch, shale and carbonate units

No. of samples

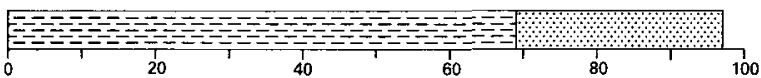

Silt samples

Sand samples

Fig. 54. Stratigraphical distribution of stream sediments for a reconnaissance geochemical survey of Peary Land. 